\title{
Yesterday's Heresy- Today's Orthodoxy: An Essay on the Changing Face of Descriptive Cataloging
} Michael Gorman

This article analyses four descriptive cataloging orthodoxies of the past-corporate authorship, uniform personal headings, the main entry, and the dominance of the card catalog-and contends that each has been overthrown, overtly or covertly. It contrasts the views of Cutter and Panizzi, mostly in the latter's favor, and alludes to the pronouncements of nineteenth and twentieth century luminaries and committees on the matters under discussion. The ways in which the MARC format has influenced descriptive cataloging, for good and ill, are also treated. The article closes with a plea for reason and the application of utilitarian principles.

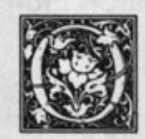

rthodoxy is my doxy; heterodoxy is another man's doxy," said Bishop Warburton to Lord Sandwich. Descriptive cataloging, that pleasant backwater of human endeavor, is as subject to the kind of situational ethics that the eighteenth century divine had in mind as is any other area of human thought. The good bishop thought of opinions and dogmas in terms of the frailties of the flesh ("doxy: a loose wench . . . sometimes: MISTRESS," Webster's Third New International Dictionary), which tells us a good deal about the Anglican Church in the bad old days. I think it is as valid to think about orthodoxies and heresy in terms of chronology. In the last thirty years, we who are involved in descriptive cataloging have seen heresies become dogmas and wild speculations become received opinions. I, as have many others, have changed some of my opinions and have seen some other opinions move from the fringes to embodiment in the very codes that regulate the largest and most influential body of descriptive cataloging -that of the Anglo-American tradition.

I seek in this essay to describe some of the changes that have occurred in descriptive cataloging of the Anglo-American tradition in the last fifty years. The most remarkable features of those changes are the way in which seemingly impregnable bastions of orthodoxy have been revealed to be as transient as sand castles and the way in which, on some occasions, the guardians of the descriptive cataloging establishment (the national libraries, the library associations, IFLA, and the rest) have proved to be as nimble as adagio dancers in adapting to the accommodation of pre-

Michael Gorman is Dean of Library Services at California State University, Fresno, California 93740. This paper is a revised version of an essay which is part of a festschrift in honour of Peter Lewis, the recently retired Director-General of the Bibliographic Services Division of the British Library. The festschrift, Eating the Menus, edited by Ross Bourne, was published by the British Library in 1989. 
viously abhorrent ideas.

\section{CORPORATE AUTHORSHIP}

Corporate authorship is as good a place to begin as any. The saintly and ingenious Sir Anthony Panizzi (the fons et origo of the Anglo-American cataloging tradition) rejected all but the smallest smidgeon of corporate authorship in his ninety-one rules. It was Charles Ammi Cutter who began the whole farrago with his breezy observation "I think that the American practice of regarding bodies of men as the authors of their own journals, proceedings, etc. . . . is preferable to the German practice of dispersing these works throughout the alphabet... " (Note the two kinds of chauvinism so characteristic of the period.) He went on, in his Rules for Descriptive Cataloging, to state that "bodies of men are to be considered to be the authors of works published in their name or by their authority." It is interesting to see that the robust "bodies of men" (redolent of Kipling at his most strenuous) are not flatly stated to be authors but are merely to be considered to be such. However hedged his rule might have been, the fact remains that Cutter had begun to stir the witches' cauldron of corporate authorship.

The nineteenth century, the time of the single author giants of descriptive cataloging, was succeeded (with almost uncanny chronological neatness) by the time of the corporate creation of the Anglo-American cataloging codes. Since the committees that were responsible for those codes were corporate entities, is it any wonder that they espoused the concept of corporate authorship? That could be accepted as mere human frailty. What is almost inexcusable is the baroque indulgence with which they elaborated on the fundamentally silly idea. Cutter's "bodies of men" were succeeded by the Rube Goldberg elaborations of the distinctions between societies and institutions and the ultimate absurdities of (for example) rules for observatories located outside municipalities and for institutions located in several places. As the years whirled down the alleys of time (1908, 1937, 1941, 1949), the whole crazy structure of corporate authorship became less and less stable. What was needed was a dose of common sense to challenge the central idiocy of corporate authorship.

Cometh the hour, cometh the man (or woman). It was the great Seymour Lubetzky who dealt the first hammer blow. It was Eva Verona who finally demolished the whole thing. Lubetzky assailed the corporate complex and tried to introduce logic into the application of the idea of corporate authorship. The only problem was that the notion of a corporate body being "chiefly responsible for the intellectual or artistic content" of a work is, except in certain narrow and infrequent cases, inherently implausible. Even Lubetzky's powerful mind was incapable of pulling off the trick of rationalizing the absurd.

"The notion of a corporate body being 'chiefly responsible for the intellectual or artistic content' of a work is, except in certain narrow and infrequent cases, inherently implausible."

In the Paris Principles of 1961, a work that emanated from a conference that was dominated by Lubetzkyan reformist ideas, we find reference to "entry under corporate body" and provisions that are considerably less sweeping than they might appear to the casual reader. What this section of the Principles represents is a political compromise between the Anglo-American comprehensive view of corporate authorship and the much narrower provisions for corporate entry found in the descriptive cataloging codes of continental Europe. Corporate authorship is not mentioned in the Principles, but entry under a corporate body is allowed in numerous cases. The idea behind the Principles was that they were to form the basis for international standardization and that the future codes that took them as their bases would be in conformity. Alas, the looseness of their wording, which was made necessary by the political compromises that made the Paris meeting 
"work," made it possible for new national codes to drive a coach and horses through the idea of international uniformity. Nowhere is this more apparent than in the use that was made of the section on corporate entry. The first edition of the AngloAmerican cataloging rules (AACR), in both its British and North American manifestations, explicitly embraced the concept of corporate authorship while claiming to be based on the Paris Principles. At more or less the same time, European codes were published which did exactly the opposite while also claiming to be based on those self-same principles. But 'twas a famous victory!

The reaction was not long in coming. Seeing that the ambiguity of the Paris Principles had made it possible for national and international cataloging codes to remain far apart on a vital conceptual question, the IFLA Committee on Cataloguing encouraged Eva Verona to do a study of corporate headings (published in 1975 as Corporate Headings: Their Use in Library Catalogues and National Bibliographies: $A$ Comparative and Critical Study) which espoused the Continental European idea that there is no such thing as a corporate author, though the limited use of corporate main entry headings in author catalogs may be justified. This distinction has the whiff of angels and pins that is characteristic of much of descriptive cataloging theory, but it did lead to an important theoretical and practical change in the second edition of the Anglo-American Cataloguing Rules (1978). For the first time since Panizzi, a major English language cataloging code abandoned the idea of corporate authorship and limited the application of corporate main entry to five (later six, see AACR2R, 1988) narrowly defined categories of works that (in the careful, if slightly otherworldly, term used in the code) "emanate" from corporate bodies.

Thus it was that the orthodoxy of corporate authorship was overthrown and the heretical "German practice" that Cutter decried reigned in its place. The ultimate irony is that one of the categories allowed main entry by AACR2 is probably the only true case of corporate authorship that has ever been. The provision to enter sound and video recordings and other works created by a performing group under the name of the group seems to me to be a recognition of a plain fact. That fact is that it is hard to dispute that, say, the Rolling Stones are the authors of sound recordings that contain songs that the group has written, performed, and produced. So, as corporate authors steal from the scene to be replaced by a few "emanators," modern society and technology have given us a type of material in which corporate authorship is indisputable.

\section{UNIFORM PERSONAL HEADINGS}

Charles Ammi Cutter was, in Paul Dunkin's phraseology, the Prophet upon whose dicta the Law of our cataloging codes was based. His most Mosaic utterance is to be found in his famous Objects of a dictionary catalog. Those few statements have been the cause of much that is good about the cataloging codes that took them unquestioningly as their basis. They have also been the cause of some persistent error and of some misunderstanding. I have never seen it pointed out that, for instance, the very first "object" makes little or no sense. It reads "To enable the reader to find a book of which ... the author is known." The fact is, of course, that if one knows nothing of a book other than the name of its author, it will be impossible to locate that book with complete confidence. Even if, in such a case, one were to find only one entry in a catalog under the name of that author, how would one know with ontological certainty that that entry represented the only book in the world by that author? The first object should read "to enable the reader to find a book of which .... the author and something else, preferably the title, is known."

The most serious flaw in the Objects, however, lies not in the first but in the fourth. This reads "To show what the library has by a given author." The way in which this object is to be achieved is stated to be "Author entry with the necessary references." In other words, the works of an author are to be gathered together under a standard heading in all cases-even when an author uses different forms of his or her name or when an author uses two or more 
different names. This ruling by the Prophet was among the most orthodox of the cataloging orthodoxies for nearly a hundred years. It caused a great deal of mischief. Works identified with one name were, until comparatively recently, to be found under other names in catalogs and, in American libraries at least-because of the infamous Cutter-Sanborn numbers-to be located on the shelves in a place other than that in which the average sensual library user would look for them.

"This orthodoxy-that all the works of a person should be collocated regardless of the inconvenience to the majority of library users-need never have happened."

This orthodoxy-that all the works of a person should be collocated regardless of the inconvenience to the majority of library users-need never have happened. That it did so is the product of two unfortunate happenings-neither of them, to my mind, the fault of the late C. A. Cutter. The first is that in this matter, as in so many others, we were following the wrong prophet. The pragmatism and intellect of Anthony Panizzi had come to a very different conclusion. In the forty-first of his ninety-one Rules for the Compilation of the Catalogue Panizzi stated, "In the case of pseudonymous publications, the book to be catalogued under the author's feigned name ... " and, in the forty-second rule, "Assumed names ... to be treated as real names." How much easier the life of the library user would have been had the cataloging profession followed the ItaloEnglish prophet rather than the American! All the works of the multinamed Ms. Hibbert and Mr. Creasey (not to mention Lauran Bosworth Paine, who is to pseudonyms what Argus was to eyes) would have been entered in the catalog and found on the shelves under the names by which those worthies wished them to be identified. "What of scholarship?" I hear the traditionalists cry. "What of the need for the researcher to survey all the works of an author in one place?" There are three answers to those questions. The first is that scholarship begins when the book is in hand and does not consist of or comprise the arduous searching for materials that is imposed on the would-be scholar by ill-organized library catalogs. The second is that the rules of Panizzi were followed for many a long year in the British Museum's General Catalogue of Printed Books-a work that a number of scholars have found to be a boon rather than an impediment to scholarship. The third answer is best put in the form of an existential question, "What is an author?"

This latter question leads to the second error that I believe to have bedeviled the question of the entry of persons using two or more names. When Cutter referred to "the works of an author" we seem to have assumed that he meant "the works of a person." I have always maintained that one person can be two or more authors. There is a well-known story of Queen Victoria being so entranced by the first of the "Alice" books that she begged the Reverend Dodgson to send her his next book as soon as it was issued. She was rewarded for her importunity, some six months later, by the receipt of a huge tome on symbolic logic or some such. This illustrates that she may have been asking the right person but was certainly asking the wrong author. Supposing Cutter had meant that distinction all along? That is unlikely because his own Rules follow the old orthodoxy on this question. However, prophets have been known to misinterpret their own prophecy and it could be that the Cutter who, shaman-like, promulgated the Objects was wiser than the less exalted Cutter who wrote his justly famous Rules.

The Paris Principles were the last statement of the old orthodoxy on multiple names. They flatly prescribed a single uniform heading for each person consisting of the name most frequently found in " his [sic] works." The 1967 AACR prescribed a single heading for such persons but gave an alternative rule that allowed entry for each work to be under the name that the author used in manifestations of that work. This, though a tip of the hat to real- 
ity, was of small utility in a time when standardization was rapidly moving from being an ideal to becoming a necessity. It was, after all, a scant year later that saw the beginnings of the MARC format and all the implications for cooperation that format represented. In 1978, AACR2 tried to wrestle with the problem anew. It revived the idea of a predominant name (thus consigning the works of the immensely serious Reverend Dodgson to the heading for the frivolous Lewis Carroll) but allowed as how, if no predominant name could be found, each work could be entered under the name found in its manifestations. This was superior to the AACR version because it prescribed only one rule and because it allowed multiple headings for certain persons. It did, however, still strive for a single heading when one could be found and it left a large grey area in which catalogers could contend happily and unendingly about whether a name was or was not "predominant." The 1988 AACR2R has taken a completely different tack-one that signifies the end, stated or not, of the old Cutterian orthodoxy. For the first time, a code recognizes that one person may have two or more bibliographic identities. For example, the poet C. Day Lewis is one bibliographic identity and the mystery story writer Nicholas Blake another, despite the fact that, outside their books, they were one and the same person. AACR2 also prescribes multiple headings for "contemporary authors" (a phrase of seductive ambiguity that could return to haunt us). Thus we see that, in the 148 years since Panizzi's ninety-one rules, we have gone from his multiple entries for persons using different names to the iron orthodoxy of the standard heading for each person to a code (AACR2R) that embodies the Panizzian heresy as the new orthodoxy.

\section{MAIN ENTRY}

I have so far identified two areas, corporate authorship and headings for persons using more than one name, in which, in my view, the good guys finally won and the unhelpful orthodoxies of the past have been swept away in favor of a more sensible and user-oriented approach. The next orthodoxy, that of the dreaded main entry, still lingers on as, in the family of catalogers, the mad uncle in the attic that everyone wishes would go away but stays, in apparent good health, as an embarrassment to one and all. It has been pointed out, time after weary time, that the notion of the main entry-that is, a heading that is the chief access point and, thus, of more importance than the other "added" access points-is one that belongs to a longgone era of library technology. The book catalog has, to the sadness of some, gone the way of the dinosaurs. Like them, it was too large and slow moving to survive in a changing world. One can see the attractions of the main entry in such a context. In the time of homemade catalog cards, the weary task of typing or writing the cards is ameliorated if all the information is given on only one card, the others being quasi-references. (When bad librarians die, they are sent to a special bibliographic hell in which they type and file catalog cards for all eternity.) However, the Library of Congress has been supplying printed cards for nigh on a century and such have been available from other sources for all of the last half of this century. Why then do we persist in the foolishness of the main entry, devoting 72 pages out of the 677 (over 10 percent) of AACR2R to this perfectly absurd topic?

There are those, most notably Seymour Lubetzky, who base their support for main entry on philosophical grounds. There are those who drag in ancillary topics such as single-entry listings and, gawd help us, Cutter-Sanborn numbers (the only bibliographic feature more futile than the main entry). There are those who see the main entry heading as a useful organizing device in classified catalogs, shelf lists, and the like. I find none of these arguments persuasive and am perfectly certain that the main entry is a bibliographic ghost that haunts current and future machine systems. The true reason why the orthodoxy of the main entry still prevails is that it is required by the MARC format. People used to write articles called "Is the main entry dead?" The answer to that question is "Yes, but the MARC format has embalmed it." MARC is, essentially, a 
catalog card encoded for machine manipulation. This fact (disputed as it may be by revisionist historians) has had many sad consequences. One of them is that the hapless cataloger in the wanning years of the twentieth century still has to decide which access point she or he is to put in the " $1 X X$ " field, and, therefore, needs those otherwise unnecessary seventy-two pages of the cataloging code.

Is the situation hopeless? I think not. Committees and catalog code editors may continue-boats beating against the current-to affirm the importance of the main entry. The crushing weight of the MARC establishment may forbid the kind of reconstruction of MARC of which the abolition of main entry is but a part. Like the Austro-Hungarian empire, however, the glittering surface is but a shadow and the realities press ever inward. In many existing online catalogs and, I would suggest, in all online catalogs to be, there is no operational distinction between a main entry "heading" and added entry "headings." Either will take the user directly, via a visible or invisible authority record, to the relevant bibliographic records. The online catalog is not content with the subversion of the idea of the main entry. The user can get to the relevant authority record and on to relevant bibliographic records, as she or he can in an even halfwaydecent online system, from not only any type of access point but also from any form of an access point. This simple fact subverts most of the bases of our cataloging codes and of the MARC record that so sedulously apes the conventions of those codes. In the real world of the electronic catalog, there is no practical difference between main and added access points and there is no practical difference between an access point and a reference to that access point. This means that the whole of the second part of AACR2 is of only marginal relevance to the creation of records for online systems. It seems as though the old orthodoxy reigns, as though distinctions between kinds of access point and between forms of access point really matter. In fact, the biggest heresy of all is triumphant in all but the codes and the trappings of the cataloging establishment.
Ironically, bibliographic description, so long the poor relation of cataloging, has proved to be the most stable and unquestioned element of the cataloging process. At the same time, the assignment of headings, for so long the glamour area, has become more and more marginal, and this aspect of descriptive cataloging, which dominated all our codes up to AACR2, may be a small part of future cataloging codes. How are the mighty fallen!

\section{"The assignment of headings, for so long the glamour area, has become more and more marginal, and this as- pect of descriptive cataloging, which dominated all our codes up to AACR2, may be a small part of future cataloging codes."'}

How long will we go on pretending that the Emperor MARC II is fully clothed? It is hard to say; the ability of those involved in cataloging to ignore the patently obvious seems above the human norm, and the vested interests of the national libraries, the creators and peddlers of MARC-based systems, and of national cataloging committees are both numerous and powerful. It does seem, however, that no human system can live indefinitely with the kind of internal contradiction represented by the forms of MARC and the cataloging codes on the one hand and the realities of online bibliographic access on the other.

\section{CARD CATALOGS}

When I began to work in libraries (when Anthony Eden was prime minister and Hampstead was still a borough and not just a state of mind), the form of the catalog seemed immutable. The long history of the provision of catalog cards by the Library of Congress had affected American libraries immeasurably and the provision of a similar service by the British National Bibliography was burgeoning. My first glimpse of the technology of cataloging was of an object that looked like an iron spinning wheel being wielded by our 
head cataloger (who had, utterly irrelevantly but to my fascination, been Piet Mondrian's landlady during Hitler's war) so that it produced metal plates with cata$\log$ records embossed on them. The good lady actually pecked out the entries letter by letter, a task that involved a lot of physical exertion. My job was to be the understrapper to another lady who produced, on another alarming looking and inky machine, the requisite sets of catalog cards for the main and branch catalogs. The thing that struck me like a thunderbolt was how clever it was to produce a lot of standard entries and add the different headings rather than to type out each card in a set. I was at a very impressionable age but it still, more than three decades later, seems like a pretty good idea. The point of these autobiographical ramblings is not just to recall the dear dead days but to point out how utterly everything has changed about the physical form of our catalogs. The orthodoxy of the period was that the card catalog was the ne plus ultra of catalogs and that advances in technology, up to and including the MARC format, would be devoted to the speedier and more cost-effective production of those 3by-5-inch cards. The only dissension that I can recall came from those who, rather than foreseeing new kinds of catalogs, predicted a future in which catalogs (and, indeed, libraries) would be irrelevant. I forget which particular kind of "patent double million magnifyin' gas microscope of hextra power" was going to accomplish this great feat, but the paperless society boys were with us then as now.

\section{"The card catalog orthodoxy has been completely demolished."}

The card catalog orthodoxy has been completely demolished. Planning to maintain a card catalog indefinitely in any but the tiniest libraries is the bibliographic equivalent of wearing spats. How could this have happened in such a relatively short time? The answer is, I think, twofold. One is that the computer revolution has transformed almost all the practical aspects of life in the soi-disant First World. This is inescapable but easily confused by the easily confused. In our particular neck of the woods, many, including some librarians and almost all "information scientists," are seduced by the transformation of the practical aspects of life into a belief that the nature of things has changed. They believe that the fundamentals of librarianship are different when, of course, it is the means of carrying out our abiding mission that has changed. In the case of cataloging, we have always wanted to make our materials as accessible as possible in as speedy a manner as could be. We have always wanted to create huge cooperative union catalogs (a concept as old, almost, as librarianship itself). We have always wanted to share the burden of cataloging with others. We have always sought to standardize cataloging procedures. The century and a half of Anglo-American cataloging codes stands witness to the latter. What has changed is that we now have a technology that enables us to do the things for which we have hungered. The second reason for the overthrow of the card catalog is luck. In many ways we have blundered into the future. By and large, our fortune is that schemes toward one end have, happily, ended up by producing another and better result. The most obvious example of this latter is the MARC format. Despite its many shortcomings and despite the fact that its true origin was the sustaining of the Library of Congress' immensely profitable card service and, in Britain, maximizing the cost-efficiency of the production of the British National Bibliography and its cards, MARC has proved to be a mechanism that has made the creation and maintenance of online systems possible. This is not to say that it would have been far better had we had a format that was rethought to deal with the necessities of computerized catalogs. It is merely to say that MARC, the only available system, proved, almost by accident, to be up to the task.

Another example of backing into the truth is the formation of the bibliographic networks-most notably the OCLC 
meganetwork - that were intended to provide shared cataloging (mostly via the provision of catalog cards) and have ended up being the providers of MARC tapes for local online catalogs; the providers of effective interlibrary loan services; the potential providers of CD-ROM catalogs and other high-tech wonders; and the only effective and current union catalogs in the whole history of librarianship. In the future they will, no doubt, provide hitherto undreamed of service to automated libraries (for example, direct connection to private sector indexing and abstracting services for libraries with online systems). I applaud all these present and future good things, merely pausing to remark that those who see in this progress the fulfillment of deep and prescient plans are surrendering to the human desire to believe that those in authority have been vouchsafed some wisdom to which we cannot aspire. The truth is that most of what has been predicted about the future of the catalog has proved to be wrong and that most of the advances in the technology of the catalog have been the result of happenstance and the ability of a strategically placed few to recognize an opportunity when it swims into their ken.

\section{THE FUTURE}

It is my view, then, that the orthodoxies about, inter alia, corporate authorship, the treatment of persons using two or more names as authors, the main entry, and the forms in which catalogs are pre- sented to the library user have been overthrown, either overtly or covertly. Does this mean that they have been replaced by new and equally foolish orthodoxies? I think not. It is my belief and my hope that we are in a time of realism in the field of cataloging - a time in which dogma and theory are being forced to yield place to the exigencies of the practice of librarianship in the electronic world of today. I am, in librarianship as in other aspects of life, a Benthamite. If one believes in the greatest happiness of the greatest number and applies that belief to the wonderfully democratic catalogs that modern technology has made possible, discussions of the arcana of cataloging become less and less relevant, if no less absorbing to the surviving handful of cataloging mavens.

Cutter famously wrote of the passing of the golden age of cataloging (in 1904). I do not believe that age has passed or, in fact, has yet been achieved. The age of the petty discussion of petty aspects of the lore of cataloging may well have passed, but the age of the creation and maintenance of catalogs that meet the needs of the mass of people-catalogs based on utility rather than dogma-has only just begun. O'Shaughnessy wrote

... each age is a dream that is dying

Or one that is coming to birth

We can still be, in his famous words "the dreamers of dreams," as long as we remember that the death of orthodoxy can lead to freedom and to a new and better world.

\section{REFERENCES}

1. A.L.A. Cataloging Rules for Author and Title Entries, 2d ed., ed. Clara Beetle (Chicago: American Library Assn., 1949), 265p.

2. Anglo-American Cataloging Rules, prep. by American Library Association and others, general ed. C. Sumner Spalding, North American text (Chicago: American Library Assn., 1967), 400p.

3. Anglo-American Cataloguing Rules, $2 \mathrm{~d}$ ed., ed. Michael Gorman and Paul W. Winkler (Chicago: American Library Assn., Ottawa: Canadian Library Assn., 1978), 620p.

4. Anglo-American Cataloguing Rules, $2 \mathrm{~d}$ ed., ed. Michael Gorman and Paul W. Winkler, 1988 rev. (Ottawa: Canadian Library Assn.; London: Library Assn. Publishing; Chicago: American Library Assn., 1988), 677p.

5. Catalog Rules, Author and Title Entries, comp. by committees of American Library Assn. and (British) Library Assn., American ed. (Chicago: American Library Assn., 1908), 88p.

6. Charles A. Cutter, Rules for a Dictionary Catalog, 4th ed. (Washington, D.C.: Govt. Print. Off., 1904), 173p. (Special report on public libraries, part II, U.S. Bureau of Education). 
7. Paul S. Dunkin, Cataloging USA (Chicago: American Library Assn., 1969), 159p.

8. Seymour Lubetzky, Cataloging Rules and Principles: A Critique of the ALA Rules for Entry and a Proposed Design for Their Revision (Washington, D.C.: Library of Congress, 1953), 65p.

9. Anthony Panizzi, Rules for the Compilation of the Catalogue. The catalogue of printed books in the British Museum, V.1 (London: British Museum, 1841).

10. [Paris Principles]. Statement of principles adopted at the International Conference on Cataloguing Principles, Paris, Oct. 1961, annot. ed., with commentary and examples by Eva Verona and others (London: IFLA Committee on Cataloguing, 1971).

11. Eva Verona, Corporate Headings: Their Use in Library Catalogues and National Bibliographies: A Comparative and Critical Study (London: IFLA Committee on Cataloguing, 1975).

\section{IN JANUARY 1990 COLLEGE \& RESEARCH LIBRARIES}

The Paradox of Public Service: Where Do We Draw the Line?

by Rebecca R. Martin

Reviving a Retrospective Conversion Project: Strategies to Complete the Task by Jay Lambrecht

A Social History of Madness; or, Who's Buying This Round? Anticipating and Avoiding

Gaps in Collection Development

by Paul Metz and Bela Foltin

The Representational Rights of Academic Librarians: Their Status as Managerial Employees and/or Supervisors under the National Labor Relations Act

by Ronald L. Gilardi

The Serial/Monograph Ratio in Research Libraries: Budgeting in Light of Citation Studies

by Robin B. Devin and Martha Kellogg

The Do-It-Yourself Move for a 1.5 Million-Volume Library

by Pauline S. Bayne 